\title{
3D GPR Mapping for Excavation Plan in Jeniang, Kedah, Malaysia
}

\author{
Norhidayahti Mohd. Muztaza, M. Mokhtar Saidin, I. N. Azwin, and S. Rosli
}

\begin{abstract}
Geophysical technique is a non-destructive method that widely used in archaeology especially in detecting and mapping buried object. Archaeological features and information acquired from the geophysics data gives an advantage for archaeologist to plan for archaeological research framework especially in optimizing the excavation work. Many techniques are applicable for archaeological investigation, depending on research objective. Ground Penetrating Radar (GPR) is one of the geophysical methods that utilizes electromagnetic waves to record relative position and shape of archaeological feature in 3D. This method was applied in detecting buried archaeological structure in Kampung Sungai Perahu, Jeniang, Kedah. The purpose of this application is to plan an excavation strategy due to the location of the site which is near to a local resident. GPR with 3D interpretation managed to locate buried objects in KSP'12 study area. Excavation has been conducted based on the result obtained from 3D GPR mapping. Besides, the result from this study may be used to detect similar archaeological findings for future research.
\end{abstract}

Index Terms-Site KSP'12, Jeniang, 3D GPR survey, archaeological structure.

\section{INTRODUCTION}

Geophysical technique has commonly being used in archaeology as a non-destructive method. This method allow subsurface features to be located, mapped, and characterized by making measurements at the surface that respond to a physical, electrical or chemical property [1]. A variety of geophysical methods are applicable to the investigation of an archaeological site. Geophysical properties measurement of the ground surface produced images of subsurface that could be interpreted by the 'incollaboration' of geophysicist and archaeologist in identifying subsurface features of cultural origin [2]. Ground Penetrating Radar (GPR) is a near surface geophysical technique that most effective with buried site existing artifacts and features of interest that are located within 2-3 meters from surface, also occasionally been used for more deeply buried site [3]. In 1990 and 1992, a discovery of an archaeological structure in the district of Jeniang was reported. The findings were informed by local resident of Kampung Kalai (Fig. 2) and Kampung Gading (Fig. 3)

Manuscript received on August 9, 2012; revised September 18, 2012. This work was supported by Universiti Sains Malaysia (USM), under Sungai Batu Grant.

Norhidayahti Muztaza and M. Mokhtar Saidin are with the Centre for Global Archaeological Research , Universiti Sains Malaysia (USM), 11800 Pulau Pinang, Malaysia (Email: mhidayahti@gmail.com; mmokh@usm.my).

I. N. Azwin and S. Rosli are with the Geophysics Section, School of Physics, Universiti Sains Malaysia (USM), 11800 Pulau Pinang, Malaysia (Email: nurazwinisnail@yahoo.com; rosli@usm.my). without any further archeological research of the structures [4]. Similar archaeological structures have been discovered by USM Centre for Global Archaeological Research (USM CGAR) in 2010 at Kampung Gading, Kampung Chemara and Kampung Sungai Perahu in Jeniang, Kedah. Two sites in Kampung Sungai Perahu have been indentified of having high potential for archaeological studies, with the upper part of the archaeological structures are visible on the ground surface which located in residential area. A careful and efficient archaeological excavation strategy needs to be planned without affecting any existing modern infrastructures on site.

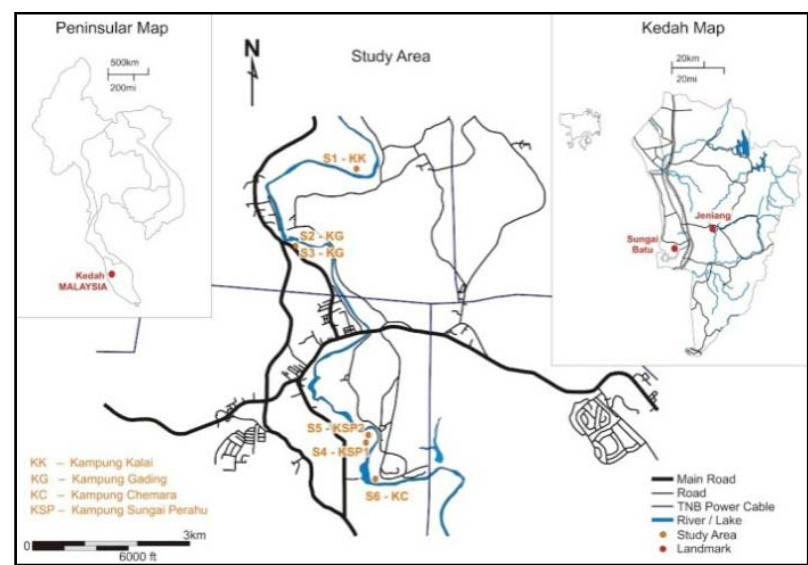

Fig. 1. Location of archaeological finding at sites in Jeniang, Kedah, Malaysia.

\section{Archaeological Structure OF Jeniang}

Archaeological structures discovered since 1990 in Jeniang are situated near the bank of Muda River (Fig. 1). It is made of clay with a shape of an earthenware jar. Trace of combustion on the inner wall of the structures show that it may have been exposed by a high temperature of burning. Excavation in 2010 by USM CGAR, discovered seven structures at Kampung Gading (Fig. 4) and four structures at Kampung Chemara (Fig. 5) with the measurement of $1.2 \mathrm{~m}$ height and $1 \mathrm{~m}$ diameter. Studies about the site are still ongoing. Preliminary study on the archaeological structure shows that it may have functioned as furnace or kiln. Other artifacts found during excavation in Kampung Chemara and Kampung Gading is small quantity of broken pottery and other artifacts that resembles iron slag. From the pattern of distribution of these archaeological findings, it is expected that there could be more sites in Jeniang with high archaeological potential, bearing similar structure. Other than determining excavation area from the result obtained by the GPR study, it can also be a reference in detecting and mapping similar buried structure for future archaeological prospection. 


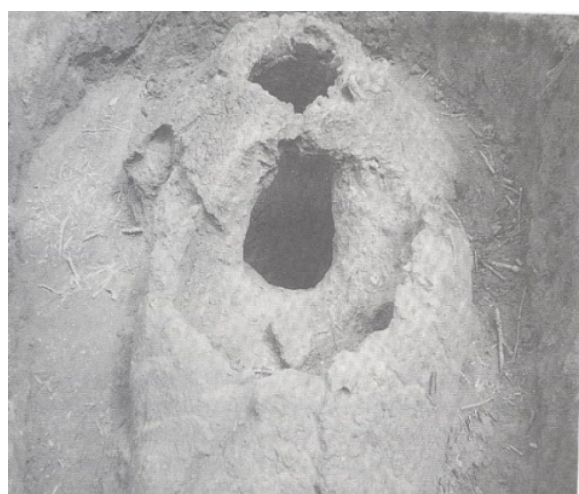

Fig. 2. Archeological structure discovered at Kampung Kalai, Jeniang in 1990.

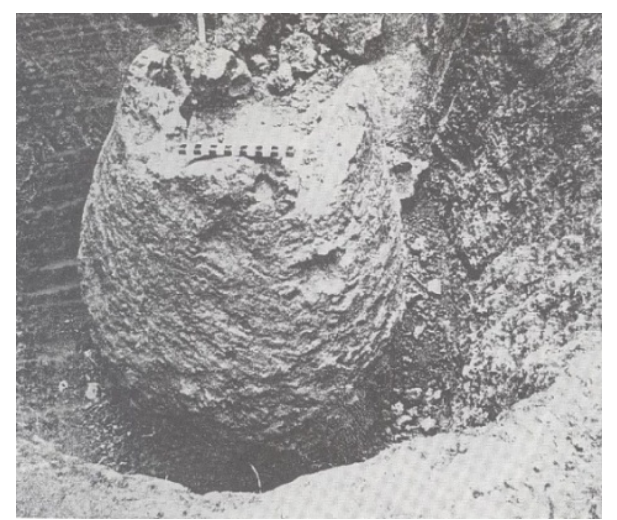

Fig. 3. Archaeological structure discovered at Kampung Gading, Jeniang in 1992.

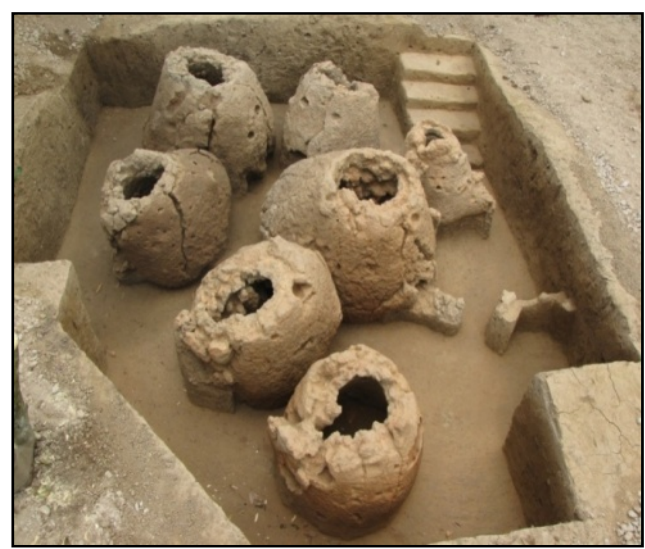

Fig. 4. Archaeological structures unearthed at site KG'10 in Kampung Gading, Jeniang on 2010.

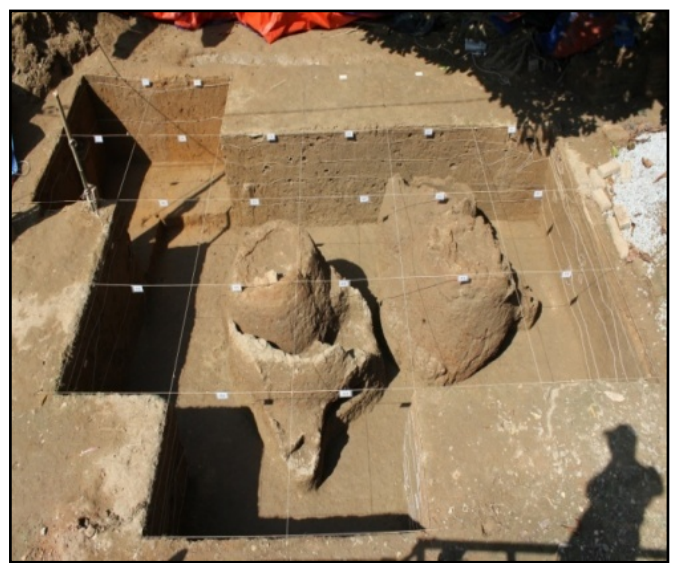

Fig. 5. Archaeological structures unearthed at site KC'10 in Kampung Chemara, Jeniang.

\section{GRound Penetrating RAdAR (GPR)}

GPR is a near-surface geophysical technique that allows archaeologist to discover and map buried archaeological features or landscape analysis, in ways not possible using traditional field method [5]. It provides high resolution imaging under the right conditions. The subsurface properties determined the depth of investigation, varies from less than a meter to over thousand meters [6]. The use of GPR in detecting archaeological remains has been used since 1970s. It was first used by the archaeologist in 1976 at Chaco Canyon, New Mexico to discover the location of walls covered by wind-blown sediment remains and has been successfully used in archaeological research framework [7]. GPR data are acquired by transmitting pulses of radar energy into a ground from a surface antenna, reflecting the energy of buried objects, features or bedding contacts and then detecting the reflected waves on the ground surface with receiving antenna. The receiving pulses will be amplified, processed and recorded to produce reflection profiles of the two-way travel time and amplitude of the reflected pulse (Fig. 6).

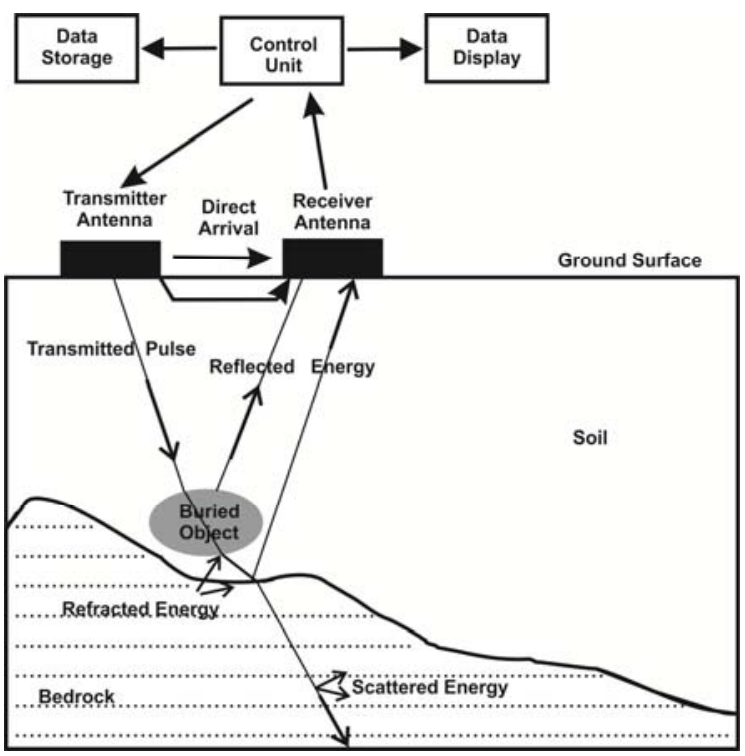

Fig. 6. GPR schematic [8].

\section{STUDY AREA}

The study area is situated near Muda River, where the upstream flow comes from the mountainous area towards southern area of Kedah. The river changes it course at the downstream and flow towards west coast after passing the confluence of mainstream [9]. Jeniang area which is located near Sik in Kedah, is part of Sungai Petani Formation. Sungai Petani Formation consisting shale, siltstone, sandstone, orthoquartzite and homologous with Mahang Formation [10]. The soil type of the study area is fine sandy clay. Physical geography of Jeniang area is flat and hilly land planted with rubber tree with settlement in a form of villages, mostly nearby Muda River and channel stream. The research area is in district of Jeniang, Kedah. The archaeological structure is located in Kampung Sungai Perahu and labeled as KSP'12 (N 5 47.648', E100 37.910') which situated near Muda River. The structure seemed to be distributed in a clustered form, with the upper part of the 
structure is visible and situated near to a resident (Fig.7).

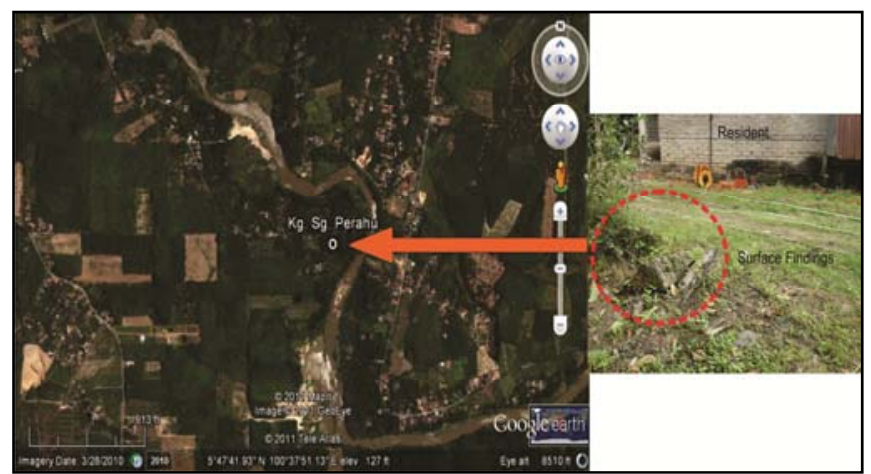

Fig. 7. The location the archaeological findings in Kampung Sungai Perahu (KSP'12), Jeniang, Kedah. There are broken pieces of the structure, visible on the ground surface and near to a local resident. (Google Earth 2011).

\section{Methodology}

GPR method are employed using $250 \mathrm{MHz}$ shielded antenna to identify buried anomalies in individual transects that might represent features of interest. A total of 10 survey lines executed in East-West direction (L1-L10) and 7 survey lines (L11-L17) oriented almost North-South direction (Fig. 8).

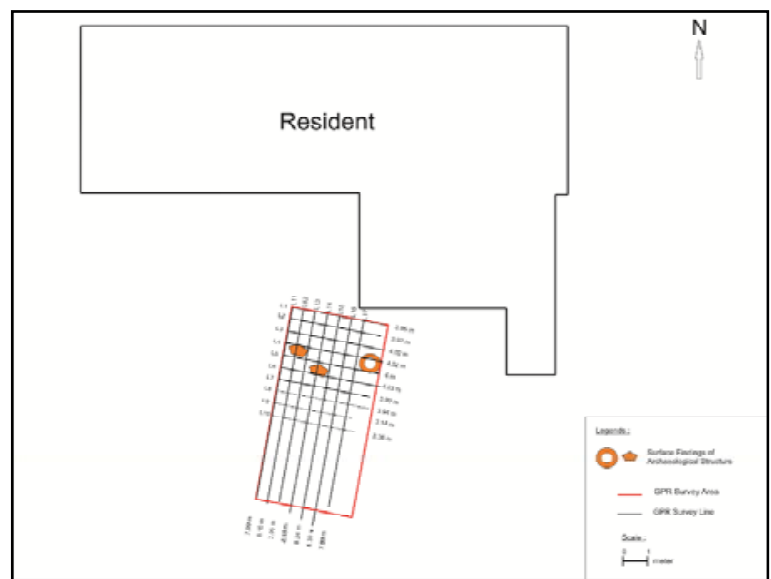

Fig. 8. GPR survey lines at site kSP’12 in Kampung Sungai Perahu, Jeniang, Kedah.

\section{3D MAPPING RESULTS AND DISCUSSIONS}

Fig. 9 shows GPR cross section of East-West survey lines. Two anomalies are detected at L7 and L8 at 1.6-2.6m and $2.3-3.0 \mathrm{~m}$ with depth of $0.24 \mathrm{~m}$ and $0.3 \mathrm{~m}$ respectively. The anomalies due to the occurrence of buried archaeological structure beneath the spotted location and supported by evidence of some surface findings (ruined structure) scattered at the surface.
Fig. 10 shows GPR section of North-South survey lines. Anomalies are detected at all survey lines except L16. L11 shows anomaly detected at $3.77-5.55 \mathrm{~m}$ with depth of $0.3 \mathrm{~m}$, while L12 and L13 at 4.24-5.55m and 4.15-5.23m with depth of $0.3 \mathrm{~m}$ respectively. There is also anomaly detected at 2.31-3.23m with depth of $0.34 \mathrm{~m}$ at L12. For L14 and L15, two anomalies are detected at $1.96-2.95 \mathrm{~m}$ and $3.64-4.65 \mathrm{~m}$ with depth of $0.32 \mathrm{~m}$ respectively. Following the anomaly flow patterns from L11-L13, the anomaly at $3.64-4.65 \mathrm{~m}$ is believe to occur due to the diffraction from base of the expected furnace or kiln as the diameter is in average of $1 \mathrm{~m}$. While for survey line L17, anomaly at 3.42-4.12m may be due to the diffraction of buried archaeological structure located next to this line that can be seen at the surface.

The study area is presented in 3-D cube with top view, side view and front view (Fig.11). Results are cut at depth $<0.3 \mathrm{~m}$ for the top view which shows an anomaly distribution. The $3-\mathrm{D}$ cube also cut at $\mathrm{x}=4.8 \mathrm{~m}$ and $\mathrm{y}=1.5 \mathrm{~m}$ distance in order to show better anomaly distribution. Fig. 7 shows the 3-D view of the study area in the North-South direction.

\section{EXCAVATION PlAN AND RESUlT}

Results from 3D GPR mapping are referred for excavation strategy at site KSP'12. Site area with high potential of having archaeological structures has been located for excavation. Grid lines for excavation trench were established, covering potential area of the buried structures. As shown from the GPR result, anomalies detected at almost all lines are proved with the existence of archaeological structures. Excavation conducted at site KSP'12 unearthed four archaeological structures which are similar with previous findings in Jeniang at site KG'10 and site KC'10 (Fig. 12).

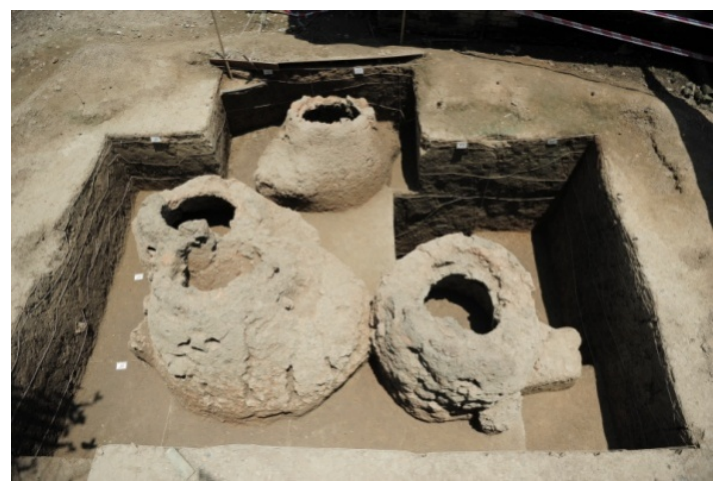

Fig. 12. Archeological structures unearthed from excavation at site KSP'12.

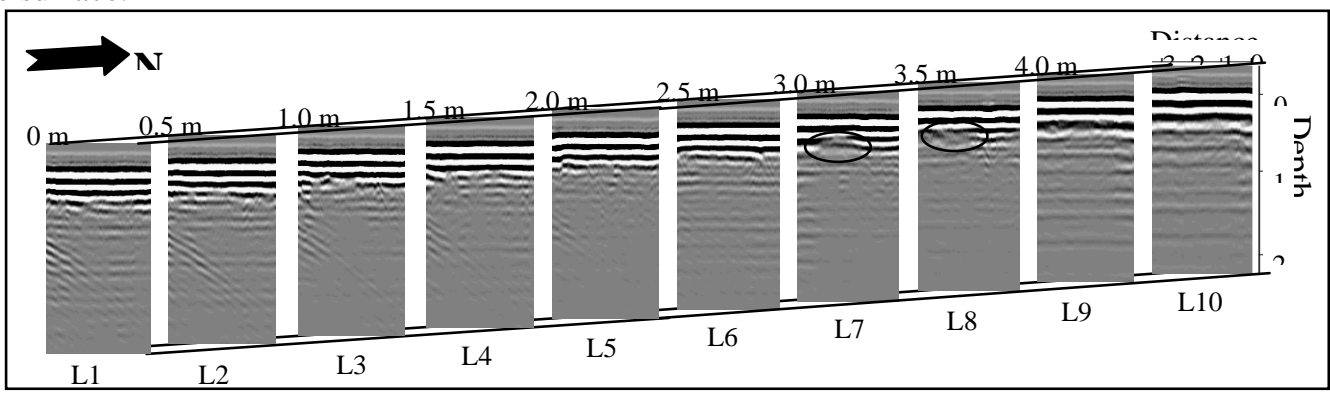

Fig. 9. Ten GPR cross sections for survey lines oriented in East-West direction. 


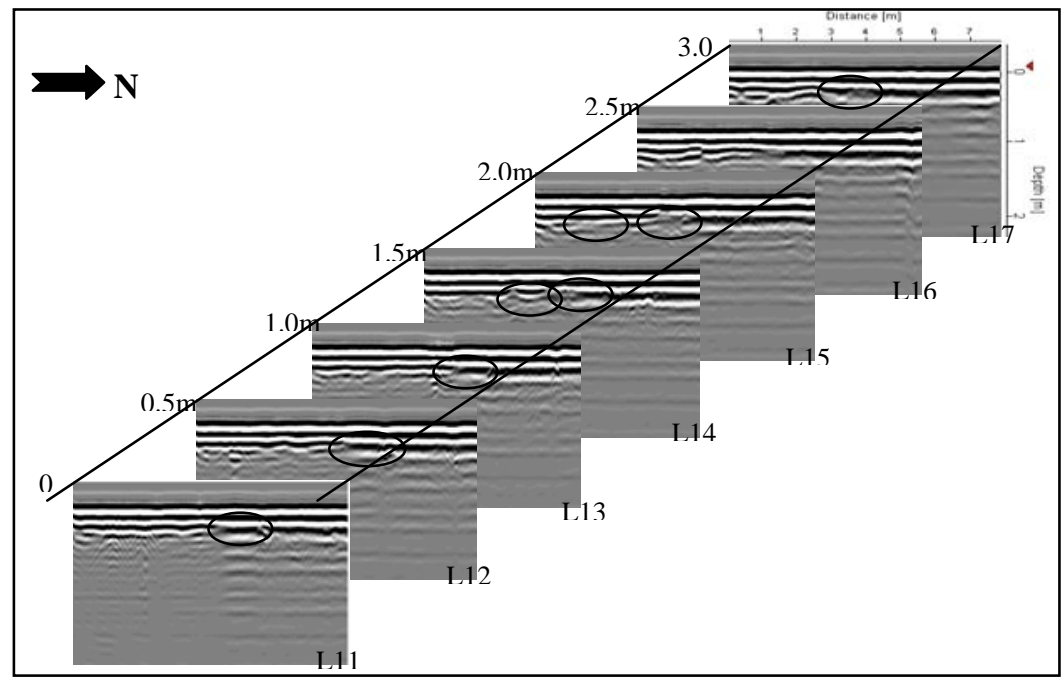

Fig. 10. Seven parallel GPR North-South survey lines. Locations of anomalies are marked with the circle.

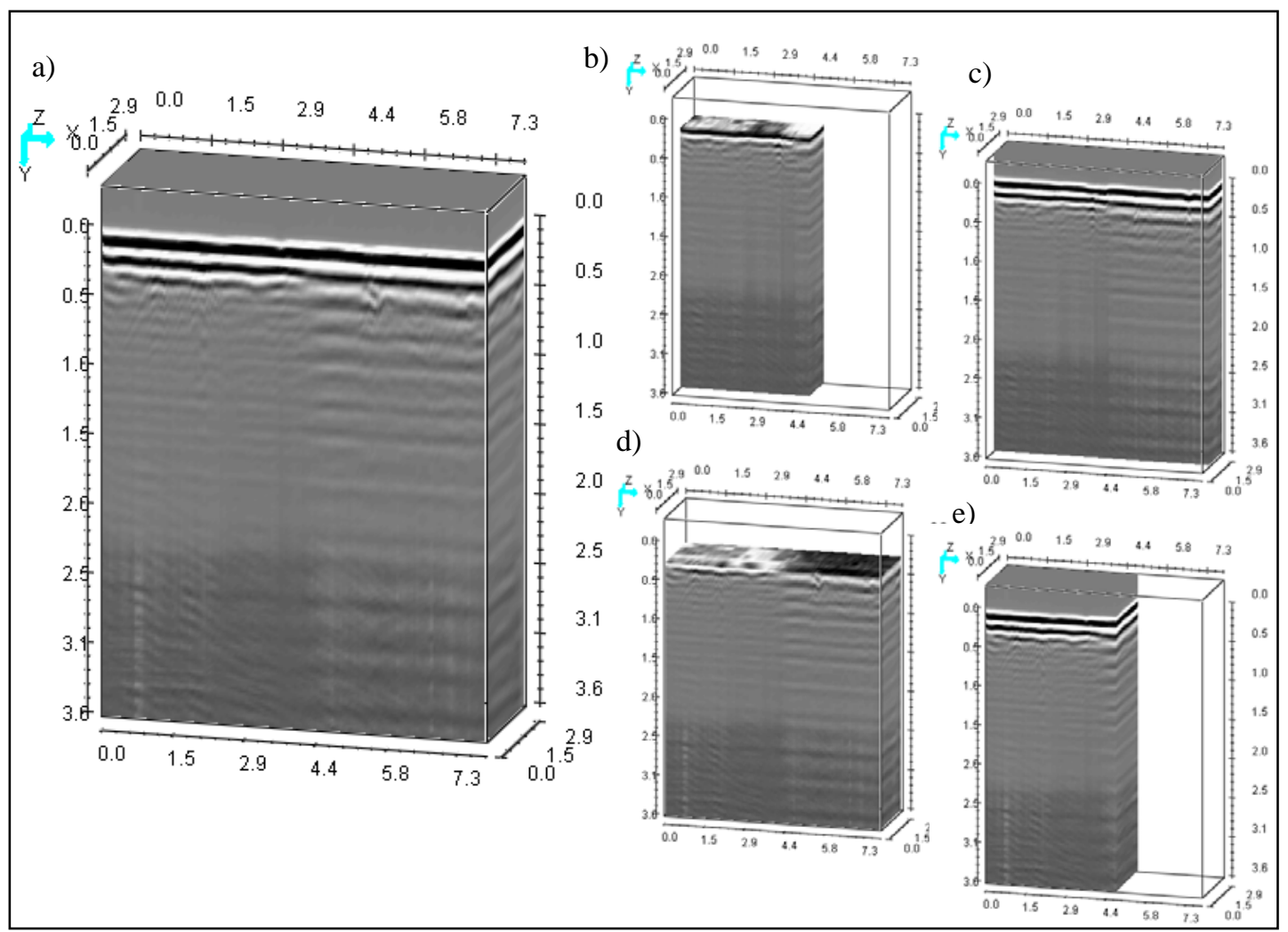

Fig. 11. a) 3-D cube of GPR data that covers area of $8 \mathrm{~m} \mathrm{x} 3 \mathrm{~m} \mathrm{x} 3.6 \mathrm{~m}, \mathrm{~b}$ ) 3 -D cube cut at $\mathrm{x}=4.8 \mathrm{~m}, \mathrm{y}=1.5 \mathrm{~m}$ and $\mathrm{z}=0.3 \mathrm{~m}, \mathrm{c}$ ) front view cut at $1.5 \mathrm{~m}$, d) top view cut at $0.3 \mathrm{~m}$ and e) side view cut at $4.8 \mathrm{~m}$.

\section{CONCLUSION}

GPR successfully detected a possible ancient furnace or kiln located at L11-L13 with depth of $0.3 \mathrm{~m}$, which is located almost the same distance with the existing furnace or kiln (surface finding). Besides giving information to plan for excavation strategy, results acquired from the study can be referred in detecting similar structures which having high potential to be found in Jeniang. 3D views give clearer image of the subsurface over the survey area where the distributions of anomalies are well mapped. GPR is useful in mapping the subsurface for preliminary evaluation of any structure that favorable with archaeology.

\section{ACKNOWLEDGMENTS}

Authors wish to express gratitude to USM Centre for Global Archaeological Research (CGAR) and USM Geophysics department for the support in this research.

\section{REFERENCES}

[1] Surface Geophysical Methods. Technos. 1. (Fall 2004). [Online]. Available: http://www.technos-inc.com/pdf/SurfaceTechnotes.pdf

[2] W. J. Johnson and D. W. Johnson, "Application of Geophysics to North American Prehistoric Sites," Archaeology Geophysics Feature, vol. 24, June 2006.

[3] L. B. Conyers. (2009). Ground Penetrating Radar for Landscape Archaeology: Method and Applications. Seeing the Unseen. Taylor 
and Francis Group, London. [Online]. Available: http://mysite.du.edu/ lconyer/landscape_archaeology.pdf

[4] M. Z. Tahir, "Laporan Penelitian Arkeologi di Kedah,” in Jurnal Arkeologi Malaysia. vol. 8. pp 50-63, 1995.

[5] L. B. Conyers, "Ground Penetrating Radar for Archaeological Mapping," Interdisciplinary Contributions to Archaeology: Remote Sensing In Archaeology, New York: Springer, 2007.

[6] G. R. Olhoeft. "Maximizing the Information Return from Ground Penetrating Radar," Journal of Applied Geophysics. vol.43, no.2, pp. 175-187. 2007.

[7] L. B. Conyers. (1998). "Ground Penetrating Radar Techniques and Three-dimensional Computer Mapping in the American Southwest," Journal of Field Archaeology, vol. 25, no. 4, pp 417-430.

[8] J. Rittenhouse. (2008). Environmental Protection Agency. [Online]. Available: http://www.epa.gov/region5superfund/sfd_fss/gpr.html

[9] A. Ab. Ghani, R. Ali, N. A. Zakaria, Z. A. Hassan, C. K. Chang, and M. S. Ahamad, "A Temporal Change Study of the Muda River System over 22 Years,” Intl J. River Basin Management vol.8, no.1. International Association for Hydro Environment Engineering and Research. pp. 25-37, 2010.

[10] E. F. Bradford, "The Geology and Mineral Resources of the Gunong Jerai Area, Kedah: Geological Survey Malaysia,” District Memoir 13.1972.

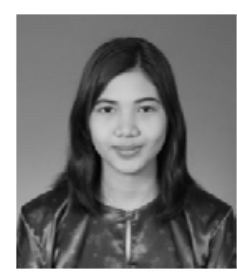

Norhidayahti Muztaza was born in Johor Bahru, Malaysia on July 30, 1987. She was graduated B.A in History (Major) \& Political Science (Minor) at Universiti Sains Malaysia (USM), Malaysia in 2010 She is currently pursuing M.A in Archaeology in the same university.

She has experienced in field excavation at archaeological site in Sungai Batu and Jeniang, both situated in Kedah, Malaysia. Her research interest is about the discovery of an archeological structure in Jeniang.

Ms. Norhidayahti has published a few paper for journal and refereed proceeding papers for conference.

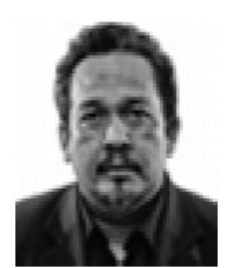

M. Mokhtar Saidin was born in Kampar, Perak, Malaysia on 15th August 1963. He is currently a Director of the Centre for Global Archaeologica Research (CGAR), Universiti Sains Malaysia (USM). He obtained his first degree in Geology at Universiti Kebangasaan Malaysia and has involved in archaeological field work since 1987. He acquired a $\mathrm{PhD}$ from USM in 1996 through a doctoral coursework at Harvard University.

$\mathrm{He}$ is the Malaysian first archaeogeologist with more than 20 years experience in archaeological research throughout the country. He has led Palaeolithic studies at sites Kampung Temelong, Lawin, Tingkayu, Bukit Bunuh, Mansuli, and civilization site of Sungai Batu, and was involved in the EIA Petronas Gas and Bakun Projects. His expertise is in the field of Palaeolithic culture, palaeoenvironment, early civilization and stone tools technology and classification. He has published several books, journals and conference papers.

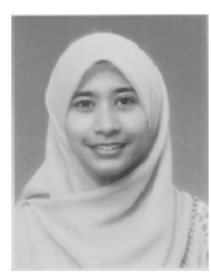

I. N. Azwin was born in Kedah, Malaysia on September 25, 1987. She is currently a post-graduate student in Universiti Sains Malaysia (USM) pursuing her $\mathrm{PhD}$ in seismic and electromagnetic wave propagation characteristics. She graduated from USM in Master of Science (Geophysics) in 2011 regarding the application of geophysical methods in engineering and environmental problems. She obtained her BSc from the same university in 2009.

She has field work experiences concerning geophysics-related in engineering and environmental projects including slope stability, groundwater exploration, constructions and also in archaeological research. Her research interest is about Geophysics in engineering and environmental study. Ms. Azwin is a member of European Association of Geoscientist \& Engineers (EAGE) and Geological Society of Malaysia.

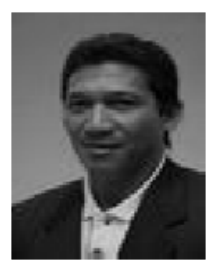

S. Rosli was born in Penang, Malaysia, on $28^{\text {th }}$ February 1960. He is a senior lecturer in Geophysics section, School of Physics, Universiti Sains Malaysia (USM). He obtained his B.Sc from Universiti Sains Malaysia in 1984, M.Sc from USM in 2004 and was awarded a PhD in 2009 from USM. He has served at USM since year 1985.

Prior joining USM, he worked as Tutor in Matriculation Centre USM and School of Physics, USM. His current research activities are Engineering and Environment. He has published several books and more than 80 journals and conference papers. 